\title{
The effect of hypnosis on the reduction of mental and physical diseases
}

\author{
Zahra Sotoudeh ${ }^{1}$, Maryam Ghorbani ${ }^{2}$ \\ 1-M.A in General Psychology, Payam Noor University, Tehran, Iran. ORCID: 0000-0003-0291-5629 \\ 2- Assistance Professor, Department of Psychology, Payam Noor University, Tehran, Iran (Corresponding \\ Author). ORCID: 0000-0002-3288-4176 \\ E-mail:ghorbani_psyc@yahoo.com
}

Received: 07/06/2019

Accepted: 21/09/2019

\begin{abstract}
Introduction: According to human studies, mental and psychological problems have an irreversible impact on the human. Today, Hypnosis is one of the treatments in many areas of medical science and psychotherapy. Specialists in this field used this treatment to improve patient`s therapy.

Aim: the purpose of this study was to investigate the effect of hypnotherapy on the reduction of psychological and physical problems.

Method: This is review article and survey some past studies conducted on the effects of hypnotherapy on the reduction of psychological and psychological problems.

Results: finding showed that is usefull in reducing the patient's problem.

Conclusion: The results have shown that hypnosis has the potential to be effective in reducing various problems in various physical and mental disorder. Therefore, hypnosis can be considered as one of the effective therapies for disorders.
\end{abstract}

Keywords: Hypnosis, Hypnotherapy , Psychological disorder, Psychotherapy

How to cite this article : Sotodeh Z, Ghorbani M. The effect of hypnosis on the reduction of mental and physical diseases. Shenakht Journal of Psychology and Psychiatry. 2019; 6 (4): 136-151 .URL: http://shenakht.muk.ac.ir/article-1-502-fa.pdf

Copyright ( $\odot 2018$ the Author (s). Published by Kurdistan University of Medical Sciences. This is an open access article distributed under the terms of the Creative Commons Attribution-Non Commercial License 4.0 (CCBY-NC), where it is permissible to download, share, remix, transform, and buildup the work provided it is properly cited. The work cannot be used commercially without permission from the journal. 


\title{
روند تأثير هيينوتيزم بر كاهش مشكلات و بيمارىهاى روانى و جسمى
}

\author{
زهرا ستوده'، مريم قربانى \\ ا. ا.كارشناسى ارشد روانشناسى عمومى، دانشكاه بيام نور، تهران، ايران.
}

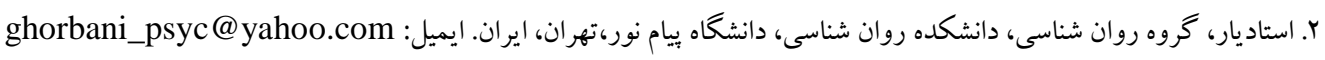

مقدمه: بر اساس مطالعات بشر، مشكلات روحى و روانى تأثيرات جبر اننايذيرى در جسم انسان مى گذارد. امروزه هيينو تيزم يكى

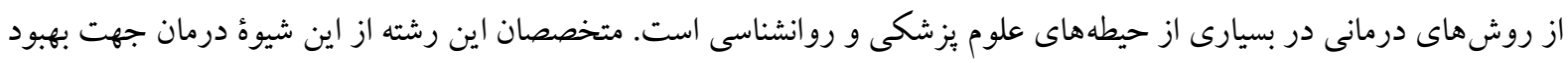
بيماران استفاده كردهاند. هدف: از يزوهش حاضر بررسى روند تأثير هيينو تيزم بر كاهش مشكلات روانى و جسمى است. روش: ئزوهش به شيوه مرورى- تحليلى است. در اين مقاله به بررسى مجموع يزوهشهاى انجامشده در زمينه اثر هيينوتيزم بر كاهش مشكلات و بيمارىهاى روانى و جسمى برداخته شده است. يافته ها: نتايج حاكى از آن بوده است كه هيينوتر ايى قابليت اثر گذارى به منظور كاهش مشكلات در زمينه هاى مختلف را دارد و

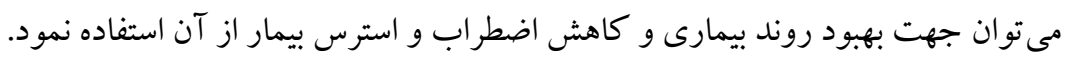
نتيجه كيرى: به نظر مىرسد هيينو تيزم به عنوان يكى از درمان هاى مؤثر در زمينه اختلالات مى تواند مورد توجه قرار گيرد. كليد وازهها: هيينو تيزم، هيينو ترابى، اختلالات روانى، روان درمانى 
است (واتكينسون، 199ץ)؛ با اين وجود در علم

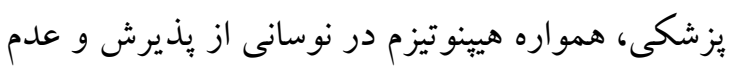
يذيرش قرار داشته است. بر اساس ديدگًاه بسيارى از محققين، پِيه و اساس هيينوترايى مدرن امروزى، مديون بزشك اتريشى بنام مسمر بودهاست كه تئورى او (امغناطيس درمانى يا وازه هيينوترايى" نام داشته است. بعدها محققين فرانسوى و بريتانيايى تئورى مسمر را

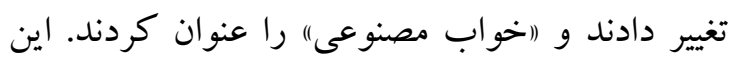
محققين معتقد بودند كه در ايجاد بديدههاى

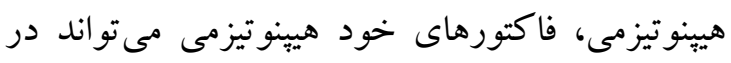
تقويت اهداف درمانى نقش مهمى ايفا كند

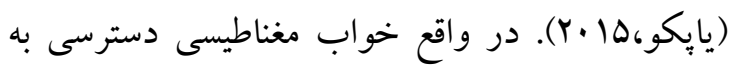
ضمير ناخود آكاه را آسانتر مى كند. به طور كلى ذهن و روان انسان از دو بخش تشكيل شدهاست: ضمير خودآكاه و ضمير ناخودآكاه. 1- ضمير خودآكاه مسئول كنترل حواس بوده و انسان را در زمانى كه

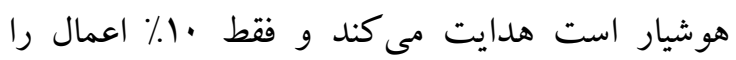
تحت كنترل دارد. ب- ضمير ناخود آكاه مسئول اعمال غير ارادى مثل ضربان قلب، تنفس، افكار و احساسات غير ارادى است. خاطرات انسان از كودكى تا هر سنى در اين قسمت بايگانى شده است و .9\% اعمال و و ه شخصيت انسان را شكل مىدهد (ويز گیى بسيار مهم ضمير ناخوداگاه تلقينيذيرى شديد آن است)(موللى،

(rV:Ir人q

تغييراتى كه هيبنوتيزم در سيستم فيزيولوزى بدن ايجاد مى كند؛ تغييراتى وسيع و همه جانبه است كه شامل تغييراتى در عمل عضلات ارادى، اعضا، غدد و ولى همجنين حواس بنج كانه و تغييراتى در سيستم ايمنى، دستخاه قلبى-عروقى، دستخاه تنفس، بخشهايى از مغز، جريان خون و امواج مغز مى گردد (زارعى،

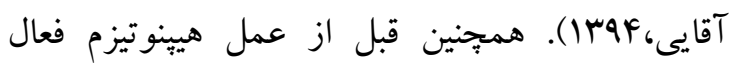

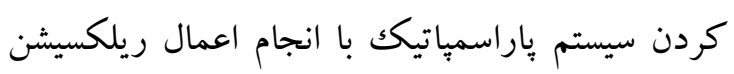

\section{مقلdمه}

روانشناسى، علم ذهن و شناخت رفتار انسانها است (رهنماى روديشتى و رسمى مازويى، روسا) و به وله بررسى فرد به عنوان موجودى مجزا مى يردازد. امروزه

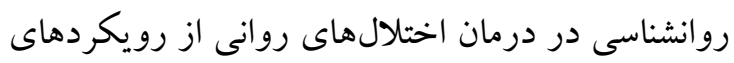
جند گانه از جمله رفتاردرمانى، درمان عقلانى -عاطفى، رونى

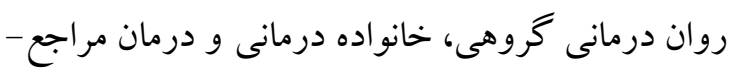

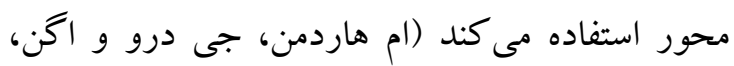

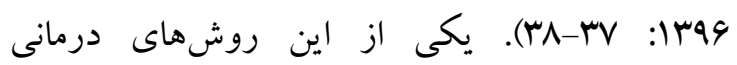
هيينو ترايى است. با وجود اينكه در طى •و سال كذشته تناقضات بىشمارى در مورد مستند بودن يديده هيينوتيزمى بيان شده است و با وجود بالينى شدن اين

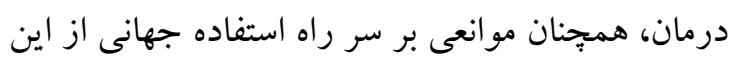
درمان وجود دارد. يكى از موانع فعلى، عدم وجود تعريفى دقيق و همكانى از هيينوتيزم است (كريج،

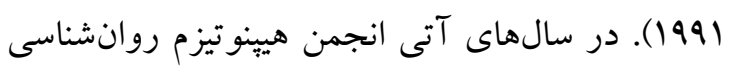

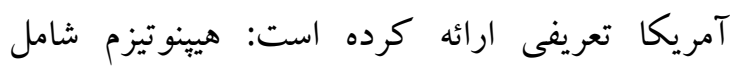

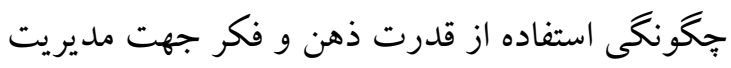
استرسهاى روحى و روانى، علائم فيزيكى ناخوشايند

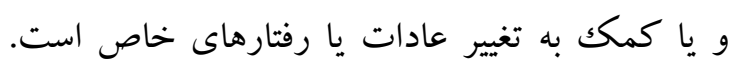

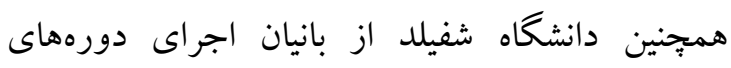
هيينوتيزم بالينى، هيينوتيزم را اين كونه تعريف كرده است: هيينو تيزم حالتى از توجه متمر كز همراه با كاهش هين آكاهى محيطى است كه ذهن نقاد سوزه، موقتاً به حالت تعليق در آمده و شخص تمايل به بذيرش عبارات و تلقينات ارائه شده از سوى هيينوتيزور را تهاب دارد. از مشخصات اين تكنيك، احساس غير ارادى بودن حركات و حسهاى تلقين شده است

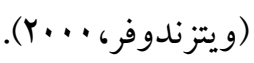
اكرجه تأثير عمل هينوتيزم درو موارد گستردهاى

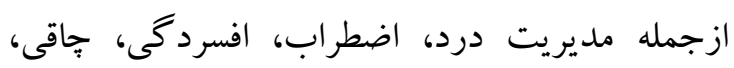
آسم، ديابت و انواع بيمارىهاى مزمن گزارش شده 
روش

يثزوهش حاضر به شيوه تحليلى - مرورى انجام گرفته و

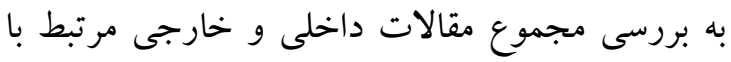

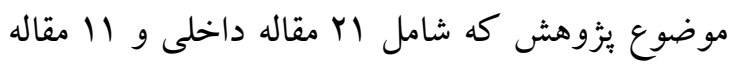

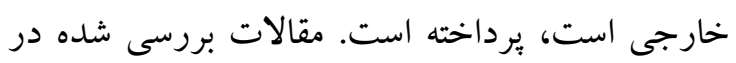

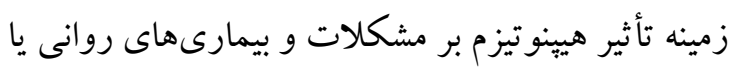

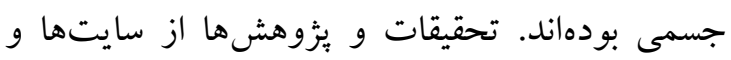

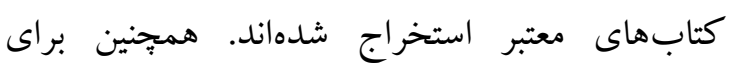
مقالات فارسى از سايت SID (بانكك نشريات فارسى ايران) و Magiran استفاده شدهاست. از ديخر منابع مورد استفاده كتب مرتبط با عنوان يزوهش از قبيل (اسرار تغييرات مثبت در انسان از طريق مديتيشن و هيينو تيزم به نگارش موللى) و (فنون هيينو تيزم درمانى به نكارش واتكينس) بوده است. مقالات خارجى نيز از سايت Science Direct استخراج شده است. ״س از بررسى و دسته بندى مقالات، يكك جمع بندى و تحليل نهايى در مورد ميزان اثربخشى هيينوترايى بر بر بردي كاهش مشكلات روانى و جسمى در قسمت يافتها

\section{يافتهها}

در اين قسمت به بررسى مقالات و بثزوهش هاى داخلى و خارجى به طور اجمالى برداخته شده است. تحقيقات

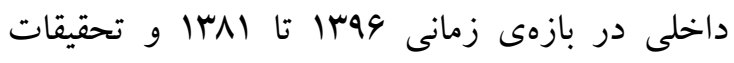

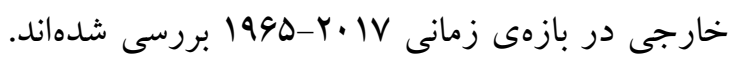
موضوع بثوهشهاى بررسى شده بر محور ميزان تأثير

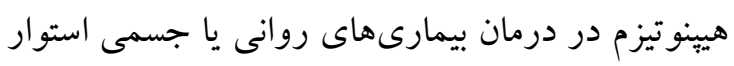

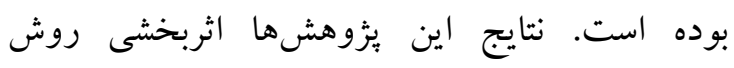
هيينو تيزم بر درمان بيمارىهاى جسمى و روحى را تائيد

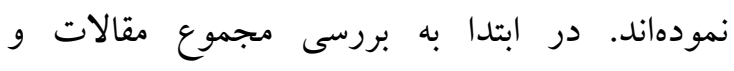
بزوهشهاى داخل كشور برداخته مىشود كه با استفاده از هيينوتيزم از طريق تلقينات درمانگر بر روى ضمير
باعث مى گردد سوزه راحت تر تلقينات درمانگر ران بيذيرد و به روند درمان سرعت بخشد (بام، ها +Y). در هيينو تيزم مناطق خاصى از مغز فعاليت دارند كه شامل:

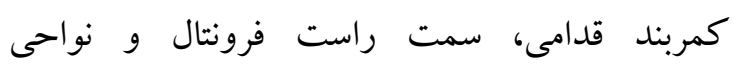
كيجكاهى از نواحى فعال مغز در مكانيسم هيينوز

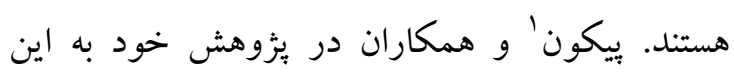

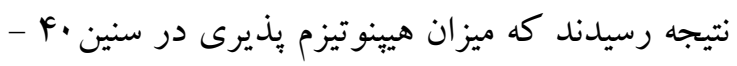

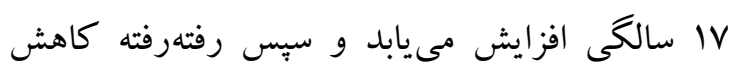

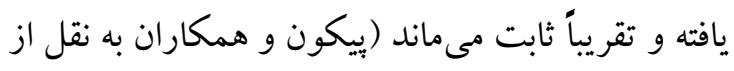

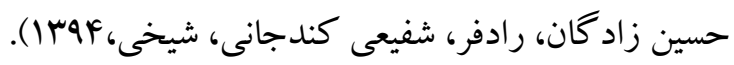

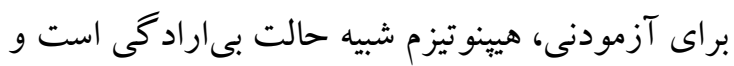

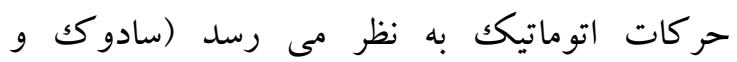

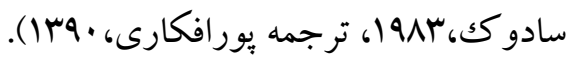
همانطور كه بيان شد هيينوتيزم يكك روش درمانى در برد روانشناسى است كه هنوز در مورد يذيرش اثر آن در درمان بيمارىها به ويزه در ايران ترديد وجود دارد. بر اين اساس در يُزوهش حاضر تلاش شده تا ميزان اثربخشى اين روش درمانى در درمان بيمارىهاى جسمى و روانى سنجيده شود تا در صورت مثبت بودن نتايج، از اين شيوه در نمايش بالينى بيش از بيش

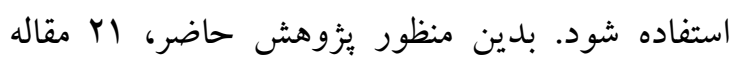
داخلى و lل مقاله خارجى كه در زمينه تأثير هيينوتيزم روى مشكلات و بيمارىهاى روانى و جسمى يزوهش انجام دادهاند بهطور اجمالى توضيح داده شدهاست. اساس اين يثوهش دستيابى به دو سؤال زير است: 1آيا هيينوتيزم در كاهش مشكلات جسمى تأثير دارد؟ Y- Tيا هيينوتيزم بر كاهش مشكلات و بيمارىهاى

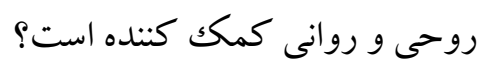


و طبى گوناگونى دارند كه مىتوان از طريق هيينو تيزم

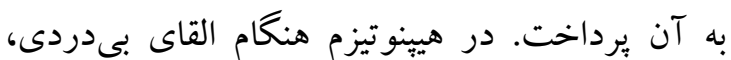
سيستم عصبى با ترشح هورمون اندروفين اين كار را

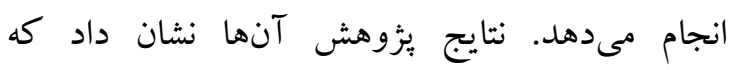

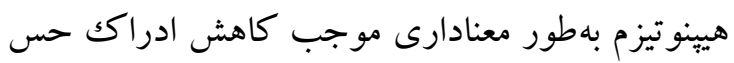
درد، ادراكك عاطفى درد، ارزيابى درد و مديريت درد مىشود. (فتحى، بور اصغر، بابايى، هوس ). در بززوهشى ديخر كه توسط فرشباف مانى صفت، ابو القاسمى، برهمند و حاجلو (هوسا) با هدف بررسى اثربخشى و مقايسه درمان شناختى رفتارى و هيبنو تيزم بر شدت درد و خودكارآمدى درد در دختران با مران ديسمنوره اوليه كار شده است، بين كروههاى هيينو تيزم درمانى و شناختى رفتارى در مقايسه ميانگينها با اصلاح بون فرونى تفاوت معنادارى نبود ولى بين

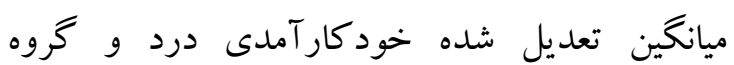
هيينوتيزم درمانى تفاوت شايانى وجود داشت. بر اين اساس درمان شناختى رفتارى و هيينوتيزم درمانى در

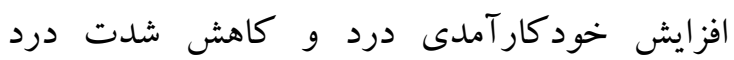
دختران با ديسمنوره اوليه اثربخش بودهاست (فرشباف مانى صفت، ابو القاسمى، برهمند، حاجلو، 94 (1). قديمى گيلى، كراسكيان، فتحى و احدى (هوبا) بر بره اساس يافتهاى يُزوهش خود دريافتهاند كه عليرغم

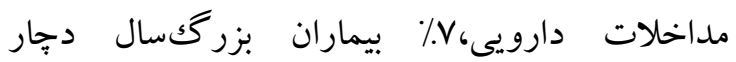
سوختگى، درد قابل توجه يا غيرقابل تحمل را تجربه مى كنند و روشهاى غير دارويى از جمله هيبنوتيزم مىتواند در كنار درمانهاى داروئى به مديريت هر جه جه بهتر درد بيماران سوختكى كمكى كند (قديمى كيلى، كراسكيان، فتحى، احدى، لهوس1).

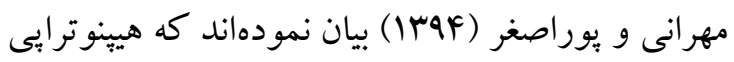
در دندانيز شكى هم يكى از تكنيككهاى ارزشمند در درمان بيماران است. آنها از بى حسى هيينو تيزمى براى تئى كاهش درد بيماران بهره ببرند و دريافتند كه مى توان از
ناخود آكاه، ذهن و روان افراد را تغيير مىدهد و اصلاحاتى در فيزيولوزى بدن آنها ايجاد مى كند. در واقع اغلب تحقيقات انجام شده به صورت تر كيبى هم روى ذهن و روان و هم بر روى مشكلات جسمانى

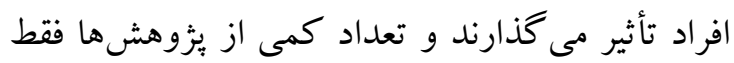

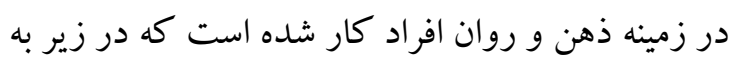
توضيح آنها برداخته شده است. يافتهاى حاصل از بثوهش هاى داخلى در بُزوهش ابراهيمى، بردنجانى و تقوايى نيا (4وسا)

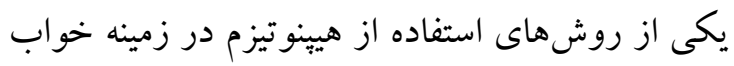
است. نتايج حاكى از آن بوده است كه هيينوتيزم درمانى بر بهبود كيفيت كلى خواب و ابعاد كيفيت

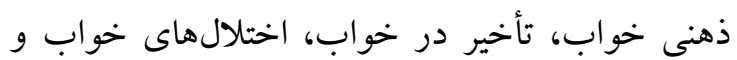
اختلالهاى عملكرد روزانه مؤثر است. هيبنوتيزم درمانى از طريق مكانيسمهايى نظير كاهش برانخيختخى

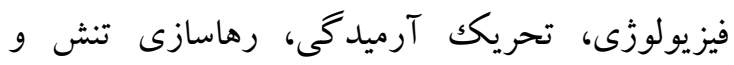
تغييرهاى شناختى كيفيت خواب افراد را بهبود مى بخشد (ابراهيمى، يردنجانى، تقوايى نيا، 94سا).

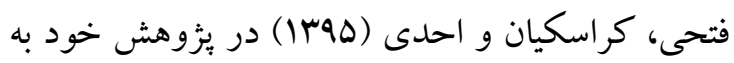
بررسى اثربخشى هيينو تيزم بر كاهش اضطراب تعويض

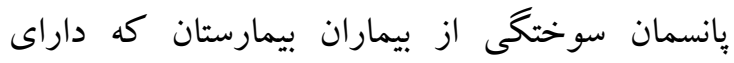

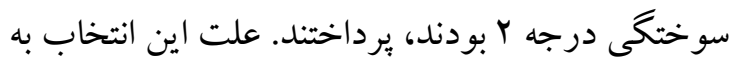
اين دليل بوده است كه هيينوتيزم يكى از روشهاى درمانى غير دارويى كارآمد در مديريت اضطراب است. يافتها حاكى از تفاوت معنادار بين نتايج

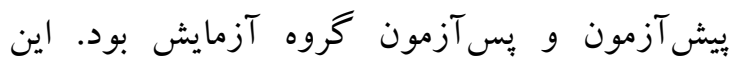

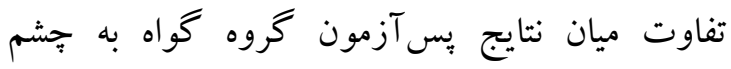
نمىخورد و در نتيجه هيينوتيزم در كاهش اضطراب

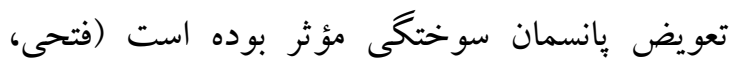
كراسكيان، احدى، هوس1). فتحى، يور اصغر و بابايى (هوب1) در إثوهش خود اذعان داشتند كه بيماران سرطانى نيازهاى روانشناختى 
در بثزوشى ديخر كه توسط زارعى و آقايى (IMAF) انجام گرفت نتايج نشان داد كه هيينو تيزم باعث تغييرات

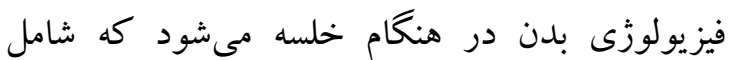
تغييرات همه جانبه هم درافزايش عملكرد سيستم

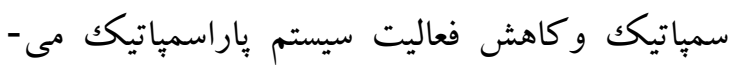
شود. همجينين در عضلات ارادى، غدد، حواس بينج گانه نوساناتى ايجاد مى كند و مغز كاملاً تحت تأثير قرار

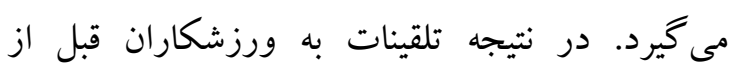
مسابقات باعث بيشرفت ورزشكاران مىشود (زارعى،

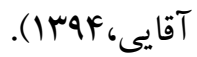

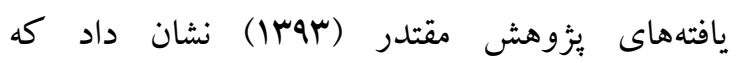
رفتاردرمانى شناختى و هيينوترايى با يكديخر تفاوت

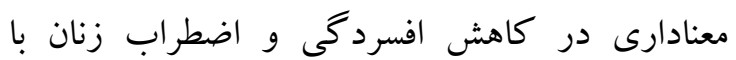
سندرم ييش از قاعدگى نداشتند و هر دو به يكك اندازه موثر واقع شدند (مقتدر، بrara). بر اساس مصاحبه بالينى 5-DSM كه لطفى فر،

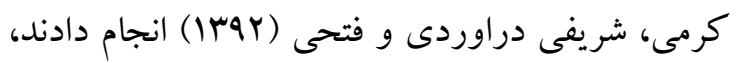
اضطراب افرادى كه ميزان اضطراب بالايى داشتند با درودي آموزش هيينوتيزم و خود هيبنوتيزمى كاهش يافت

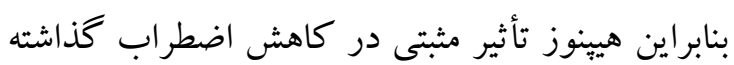

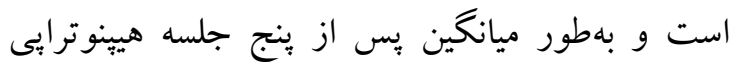

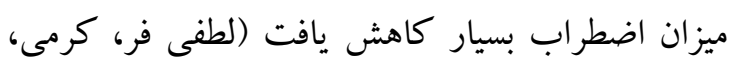

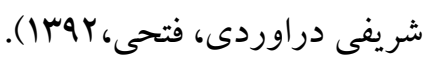
در بُزوهشى كه روى بيماران مبتلا به افسردگىى،

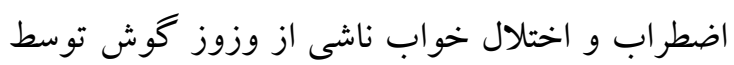

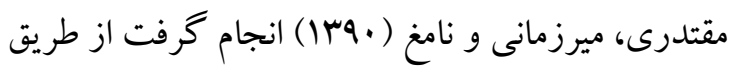

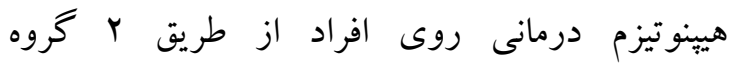
ييش آزمون و يس آزمون آزمايش انجام شد و نتايج نشاندهنده اثربخش و مفيد بودن هيينو تيزم در كاهش و و ومون

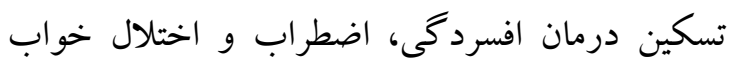

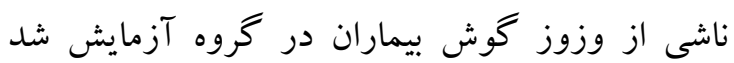

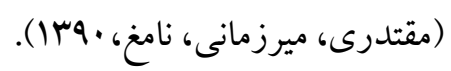

تكنيككهاى آرامش بخشى كه به بيمار القا مىشود در

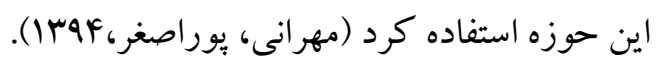

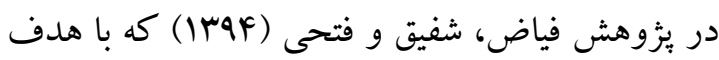
كارايى آموزش كروهى هيينوتيزم و آموزش شناختى

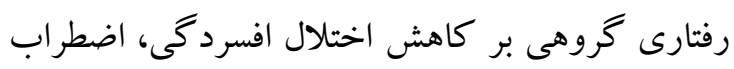

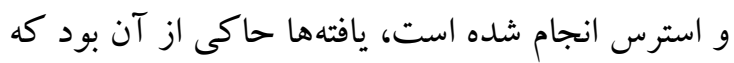

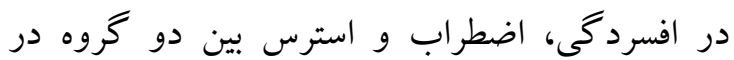
يِيش آزمون تفاوتى وجود نداشت اما در يس آزمون بعد

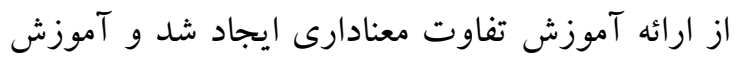

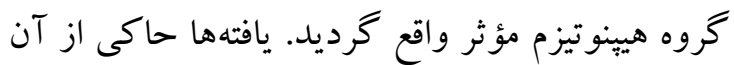
بود كه آموزش كروهى هيينو تيزم در كاهش هون اختلال

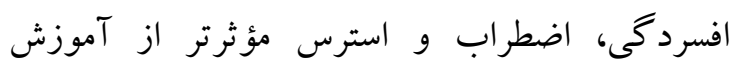

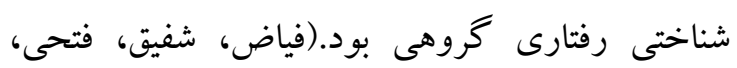
كF كندجانى و شيخى (Irqf ) كه به بررسى ارتباط بين مشخصات فردى و سطح سلامت روان با ميزان هيينوتيزم يذيرى زنان مبتلا به بيمارى مولتييل

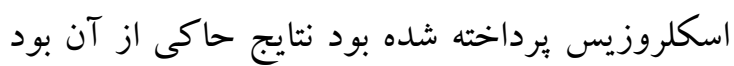
كه از ميان مشخصات فردى، فقط سن با ميزان

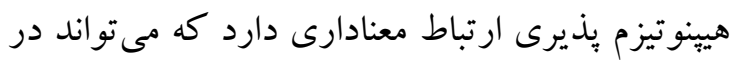
بيماران MS به خوبى مورد استفاده قرار گيرد (حسين

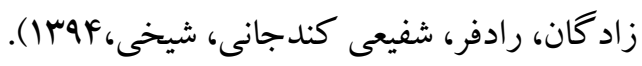

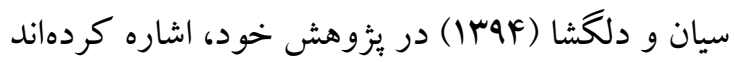
كه ازجمله مهمترين مسائلى كه مورد توجه روانشناسان علوم تربيتى است كاهش اضطراب و استرس و افزايش دقت و تمركز است. با استفاده از آزمون خط زنى نـ تولوز (آزمون بخش دقت و تمركز) قبل از هيينوتيزم

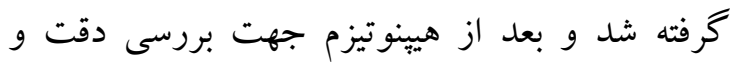

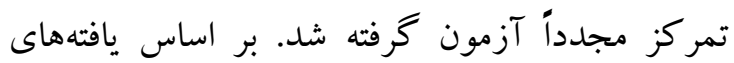
بثزوهش آنها مى توان از هيينو تيزم به عنوان روش نوين براى افزايش دقت و تمركز افراد بهره گرفت (سيان،

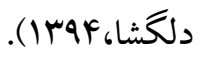


ورزش هم مفيد است. در اين يثوهش با استفاده از تلقين ها، تصويرهاى ذهنى در زمينهاى بهبود عملكرد ورزشى، تمركز فكر بهتر و آرامش بيشتر آموزش داده

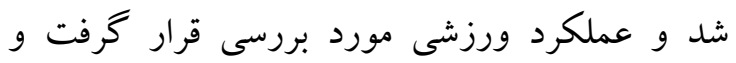
مشاهده شد كه به كروه آزمايشى كه تلقينات

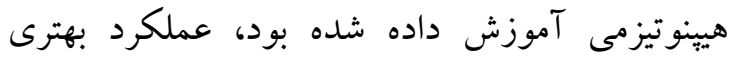
نسبت به گروه كنترل داشتند و نتايج حاكى از مفيد بودن هيينوتيزم بر روى ورزشكاران فوتسال بود

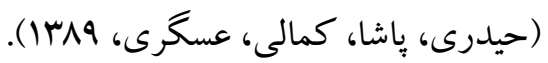

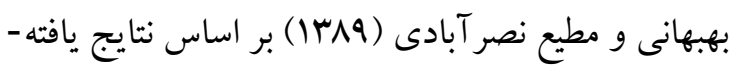
هاى خود اذعان داشتند كه تحليل سيخنالهاى EEG در حين هيينوتيزم خالص و EEG در حالت غير هيينوتيزم كاملاً باهم متفاوت هستند. در اين تحقيق

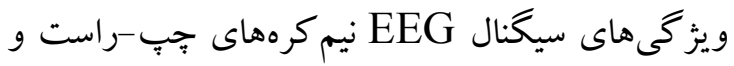
لوب قدامى-خلفى در حالت هيينو تيزم كه متعلق به سه كروه با هيينوتيزم يذيرى بايين، متوسط و بالا بودند

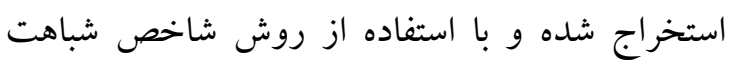
فازى مورد بررسى قرار گرفتند تا مشخص شود كه آيا رابطه معنادارى ميان فعاليت اين نيمكرهها در حالت هيينو تيزم و درجه هيينو تيزم يذيرى افراد وجود دارد يا خير. در واقع از ويزّكىهايى كه در مرحله قبل قابليت

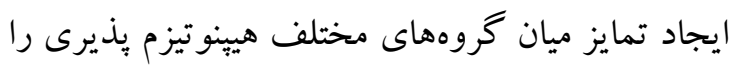

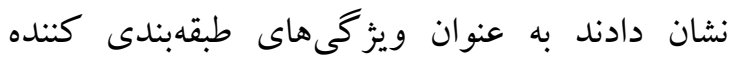
استفاده شد تا بر اساس آن بتوان افراد را به سه دسته با لبال قابليت هيينوتيزم يذيرى پايين، متوسط و بالا تقسيم كرد. همجنين تحقيقات مختلف انجام شده روى سيخنال هيينوتيزم مشخص كرد كه نيم كره راست در حالت هيينوتيزم فعاليت بيشترى دارد (بهبهانى، مطيع

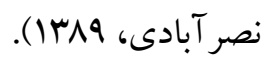
سالارى و سجادى (rMYr) در يُزوهش خود اشاره كردند كه يكى از خطرات عمده هيينوتيزم، وابستخى درمانجو به درمانكر است. همجنين بيماران بارانوئيد،

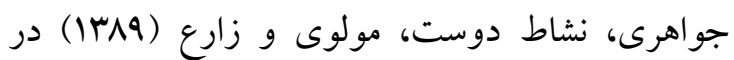
يزوهش خود تحت عنوان مديريت استرس شناختى رفتارى بر كيفيت زندگى زنان مبتلا به صرع لوب

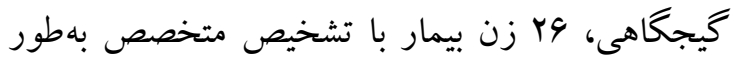
تصادفى انتخاب شدند؛ زيرا بيماران صرع دجار تحريفات شناختى و افكار ناكار آمد متعدد هستند و فعال شدن اين افكار نه تنها باعث تمركز فرد بر ظاهرش مىشود بلكه باعث نا ارزنده سازى و ناميدى وى نسبت به آينده نيز مىشود. همجنين نتايج نشان داد كه درمان شناختى رفتارى بر روى اين بيماران اثر منفى دارد و

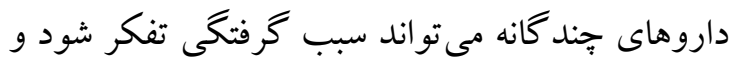
سرعت فرد در بردازش اطلاعات را يايين بياورد. در

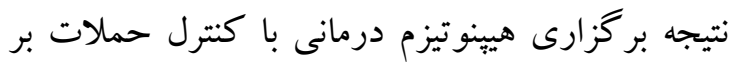
روى بيماران تأثير مثبت داشته و خود بيماران از هيينوترايى و اثرات آن بسيار راضى بودند. بعد از تحقيق به آنها توصيه شد خود هيينوتيزمى را انجام

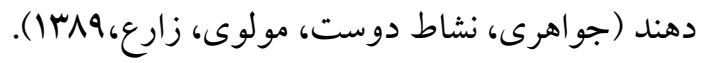

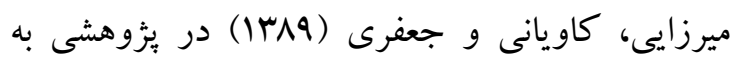
بررسى تأثير رفلكسولوزى بر اضطراب زنان نخست زائ

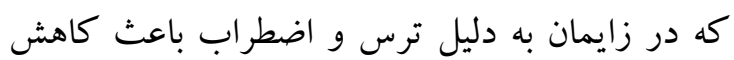
شانس زايمان طبيعى مى گردد برداخت. يافتهها نشان داد كه با استفاده از روشهاى غير دارويى مثل هيينوتيزم، ماساز، طب سوزنى، نوردرمانى، رايحهدرمانى و رفلكسولوزى مىتوان به كاهش استرس

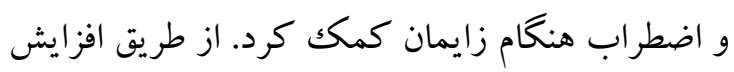

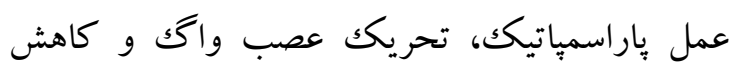
كورتيزول و نوروايى نفرين و افزايش سروتونين موجب عملكرد بهتر دستكاه ايمنى مىشود و در آخر در فرايند زايمان طبيعى باعث بهبودى در عملكرد روند

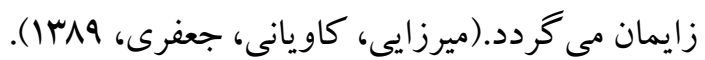

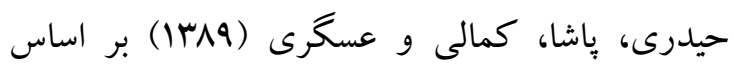
نتايج يُوهش خود بيان داشتند كه هيينوتيزم در زمينه 
در يزوهشى بيو گرى، بورگر و كادرانل (Y.IV) يكى از استفادهاى شايع هيبنوتيزم را، استفاده آن در زايمان بيان كردهاند. توانايى هيينوتيزم براى مداخله زايمان امرى ممكن وبى خطر است. براى كاهش درد در حين

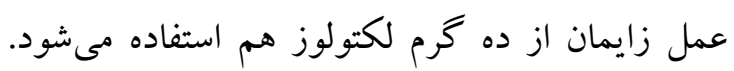
آنها در بثزوهش خودآزمايشى روى شش رانش داوطلب خانم در رده سنى | آY-YM انجام دادند. در ابتدا به افراد آرامش هيينوتيزمى در هنكام خواب داده مى شد و د در مرحله رسيدن به اوج آرامش مكرراً دستور داده مى شيد

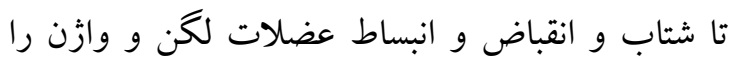
تصور كنند. بِ از جند دوره آموزش قبل از از زايمان

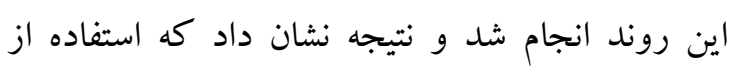

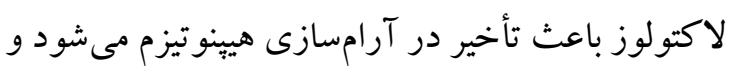
هيينوتيزم باعث آرامش و تغييرات فيزيولوزيك از جمله كاهش فشار خون، ميزان تنفس و تيش كند قلب مىشود. اين ها مخالف اعمال زايمان هستند بِ بايد براى زايمان بهتر و جلو گيرى از فعاليت بيشازحد

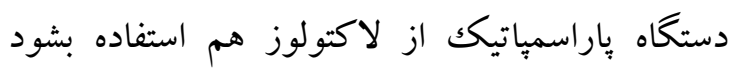

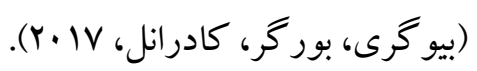

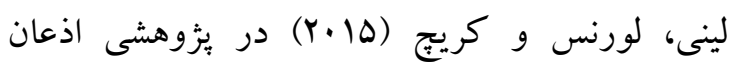
داشتند كه از جمله تأثيرات هيينوتيزم، كاهش ترس ورس و و اضطراب است كه در دندانيزشكى مورد بررسى نائى قرارگرفته و نكته جالب اين بوده است كه •م درصد

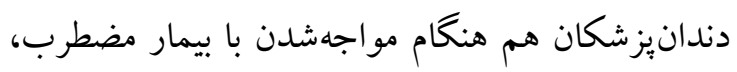

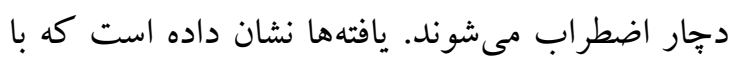
استفاده از تلقينات هيينو تيزمى مىتوان هم از اضطراب

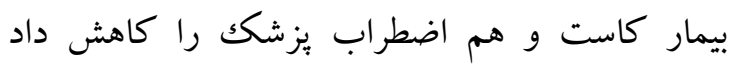

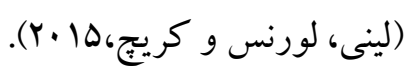

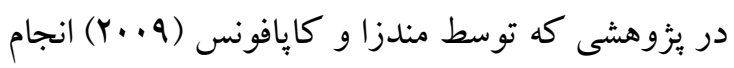

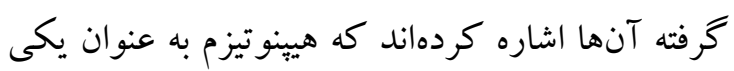
ديخر از مداخلات بزشكى يا روان شناختى استفاده مىشود كه كارايى و بهرهورى اين مداخلات را
اسكيزوفرنى و O,C,D كانديدهاى مناسبى براى

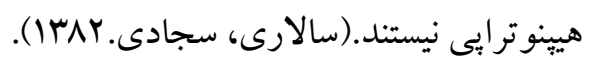
در يُزوهش علوى، محجوبى فرد، لشكرى يور و فتحى (IMNY)

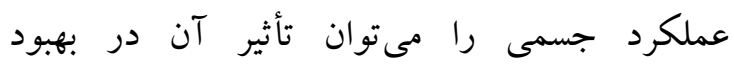
سردردهاى تنشى بيان كرد كه بيشتر در بيايان

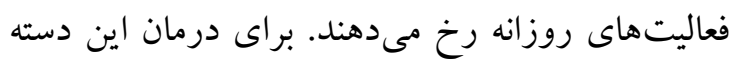
بيماران از روشهاى غير دارويى مثل القاى هيينوتيزم و شل كردن عضلات استفاده مىشود. در اين درمان از تكنيككهايى مثل شل كردن بيش رونده و تصوير سازى هدايت شده، بهرهز فته شد كه در نتيجه القاى هيينوتيزمى در درمان سردردهاى تنشى يكك روش

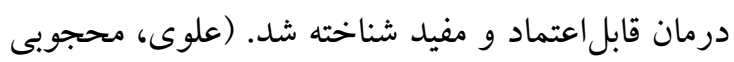

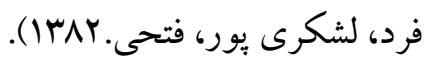

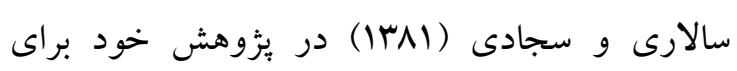
جلو گيرى از تحريفات بهعمل آمده در اغراق گويى و و اعجابآميز بودن عمل هيينوز توضيح دادهاند كه آيا اين عمل، علمى است و يا درمانى دارد يا خير. بايد كفت طبق نتايج گرفته شده ادراك واقعى + تصورات ذهنى باعث شكل گيرى درك اشياء يا افرادى مى گردد كه در اين حالت فرد آنها را مىبيند. بر اين اساس اين عقيده كه عموم فكر مى كنند فرد هيينوز شده بهطور

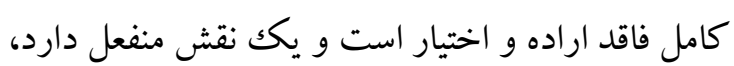
درست نيست. (سالارى، سجادى. (I) إ).

\section{يافته هاى حاصل از يزوهشهاى خارجى} اكنون به بررسى مقالات خارجى كه در زمينه هيينو تيزم و بيمارىهاى روحى يا جسمى انجام شدهاند، يرداخته مىشود و به طور اجمالى توضيحاتى در مورد اين يماني

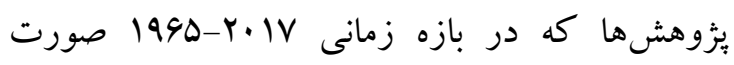

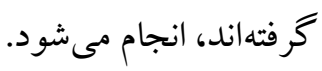


شر كت كنند كان، عمل هيينو تيزم بكار كرفته شود؛ اما شواهد علمى حقيقى براى حمايت از هر كونه ارتباط خاص بين هيينوتيزم و ايجاد بخشهايى از اسكيزوفرنيا

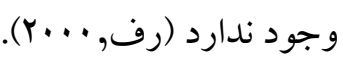
در ئزوهش سوريج و اسرينيواسان (1999) تغييرات الكوى مرتبط با خواب و آكاهى بيدارى نشان مىدهد كه تغييرات شيمى مغز در اين دو حالت متفاوت هستند و همجنين تغييرات شيمى مغز در مراحل خواب هم متفاوت مىباشند. در نتيجه در مرحله خواب REM كه رؤياها منسجم، واقعى و منظم هستند مغز توانايى تشخيص رؤيا بودن را ندارد و آنها را واقعى تلقى مى كند. در اين مرحله هر جيزى كه به فرد تلقين داده شود مى يذيرد و قادر به تجزيهو تحليل نيست و گفتتارها وارد ناخود آكاه مىشوند. به اين صورت كه به بيمار آموزش بهري خود هيينوتيزم مىدهد و در بايان دوره بيمار با نشانههايى از افزايش عزتنفس، اعتمادبهنفس و هايبرانرزى شدن و كاهش يا نايديدشدن علائم افسردگى روبهرو مىشود. (سوريج، اسرينيواسان.

.$(1999$

در بثزوهش ديخرى رف (1991) بيان داشتهاست كه هيينوتيزم مى تواند يكك ابزار مفيد براى بيماران در رفع

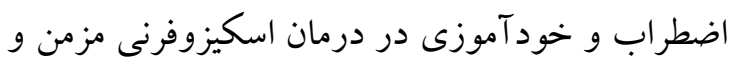
پارانوئيد مزمن واقع شود. همجنين هيبنوتيزم روش غيرمستقيم و قابل قبولى است و به عنوان يكك روش بىخطر، غير داروئى است كه اگر در زمان مناسب روى بيماران انجام شود اثرات مثبت قابل توجهى برجاى

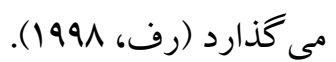

هال (199V) يزوهشى بر روى افراد مسن انجام داده

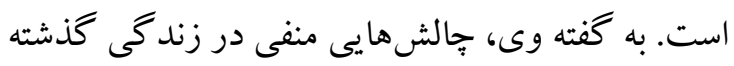
افراد مسن وجود دارد كه باعث نخران شدن رواندرمانگران مى گردد كه اين معضل با هيينوتيزم و

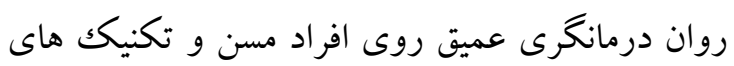

افزايش مىدهد. علاوه بر اين، اثربخشى هيينوتيزم در برخى از برنامهاى كاربردى بالينى بويزه در زمينه كنترل در جندين بيمارى بِز شكى به اثبات رسيده است. همجنين شواهد قابل قبول اثربخشى آن در درمان افسردگى، اختلالات خواب، توقف سيگار كشيدن، كاهش وزن، آسم والتهاب را به ثبت رسانده است

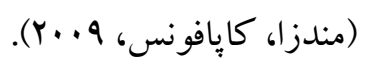

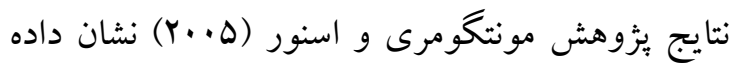
است كه هيينوتيزم براى افراد مبتلا به ديابت بسيار مفيد است. استفاده از تكنيك هاى علمى و به جا باعث مى شود بسيارى از مشكلات بزشكى كه به هزينه و زمان زيادى نياز دارد از اين طريق بهبود يابد. متأسفانه تصورات غلط درباره هيينوتيزم باعث شده از اين علم ارزشمند بهطور شايسته استفاده نشود (مونتخومرى،

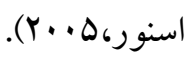

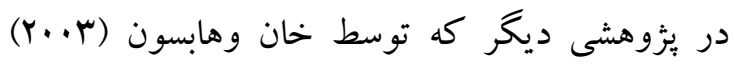
انجام شده است، خروجى ذهنى و احساسى مغز در طول خواب REM بهطور قابل توجهى از خروجى مغز در هنگًام بيدارى متفاوت است. براى به دست آوردن اين تفاوت به ارزيابى و اندازهگيرى محتواى ذهنى در حالت خواب REM و همجينين شروع خواب برداخته شده است و نتايج حاكى است از اينكه كه در حالت خواب در مرحله REM تلقين يذيرى فرد بسيار زياد است و در حالتى شبيه هيينو تيزم قرار مى گردد. در اين مرحله مىتوان محتواى ذهنى فرد را تغيير داد (خان وهابسون, r... (Y).

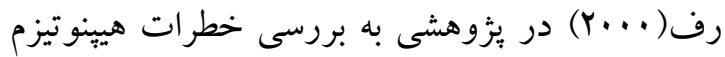

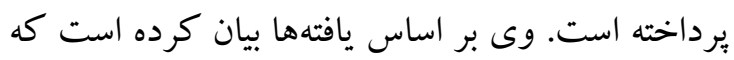
به دليل ماهيت هيينوتيزم، اين شيوه مى تواند آسيب- يكانس

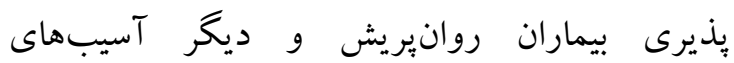
رواندرمانى را افزايش دهد. سرانجام به اين نتيجه دست يافت كه بايد با احتياط و دقت و رعايت حقوق 
از قاعدكى يرداخته است. بررسى ها حاكى از آن بود

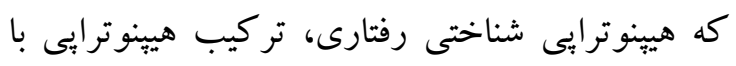
روش هاى درمان شناختى رفتارى است، جنانجه ديده

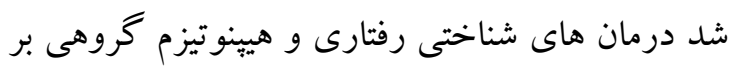

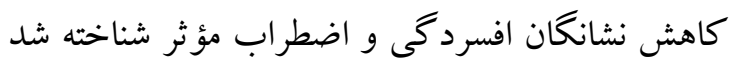
و اين دو درمان در مقايسه با استفاده از هيينوتيزم در بيهوشى هم مهم ترين نقش تاريخى را توسعه داد و در زمينه درمان بيهوشى معاصر نقش مهمى ايفا كرده است. قبل از اينكه بيهوشى شيميايى كشف شده باشد، هيينوتيزم تنها روش موجود براى تسكين درد و حتى فراتر از مصرف الكل و ديخر داروهاى سنتى ارزش داشت (جوينز، (19VD). در دهه هاى اخير افزايش قابل توجهى در استفاده از تكنيك هاى هيينوتيزم در برنامه هاى آموزشى متخصصان روانشناسى گنجانده شده است. طبق نتايج به عمل آمده از تحقيقات لوينه و لودويگك (1990) در زمينه اثربخشى هيينوتيزم، اين روش در درمان بيمارى هاى جسمى مانند ديابت، بهبود روند شيمى درمانى و كاهش درد، درمان جاقى و همجينين در درمان

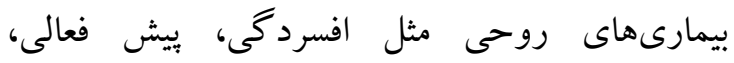
اضطراب هيينوترايى نقش مهمى را در بهبود بيماران ايفا مى كند (لوينه، لودويخ،، 1990). به منظور تجزيه و تحليل دادهها مجموع ئزوهشهاى انجام شده به شكل جدول شماره ا و ب ارائه شده است.
اريكسونيايى و تعاملات طولانى مدت برستاران و روان

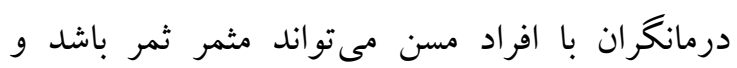
مىتوان اضطراب و افسردگى افراد مسن را بهبود بخشيد و معضلات كذشته را در ذهن آنها با كُ كرد

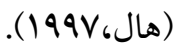
واتكينسون (199V) بيان داشته است كه خاطرات ناكوار و تلخ و اضطرابآور كه در زندگى افراد رخ مىدهد در ضمير ناخود آكاه ثبت مىشود و باعث تأثيرات منفى

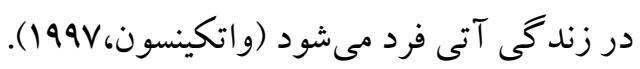
در تحقيق ديخر كه مربوط به خود هيينوتيزمى است و وردو

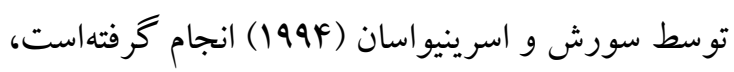

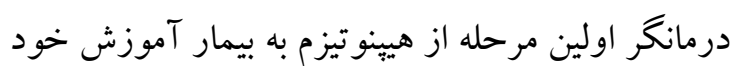
هيينوتيزم مىدهد و براى وى تجويز مى كند كه خود

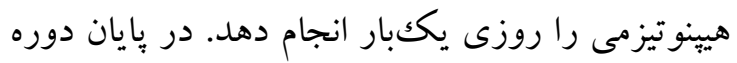
با نشانهايى از افزايش عزتنفس، اعتمادبهنفس و و هايبرانرزى شدن فرد مواجه مىشويم و كاهش يا

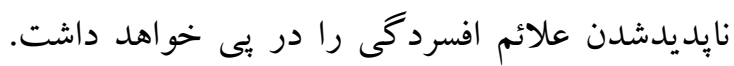

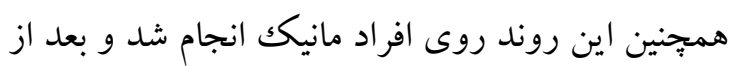
•ا روز كه روزى يككبار خود هيينوتيزمى را انجام دادند نشانهاى بىخوابى، تحريككيذيرى بالا، لجوج شدن، مهاجمى بودن، بعد از معاينات نشان داد كه شخص از اين اختلالات رهايى يافته است (سورش،

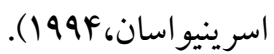

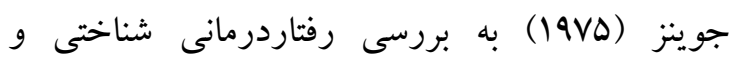

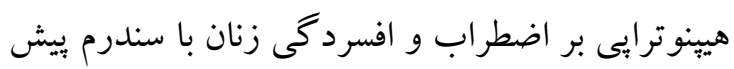

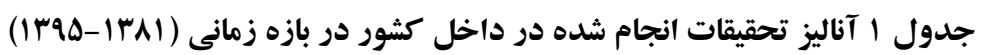

ئزوهشخران ئزوشخر/

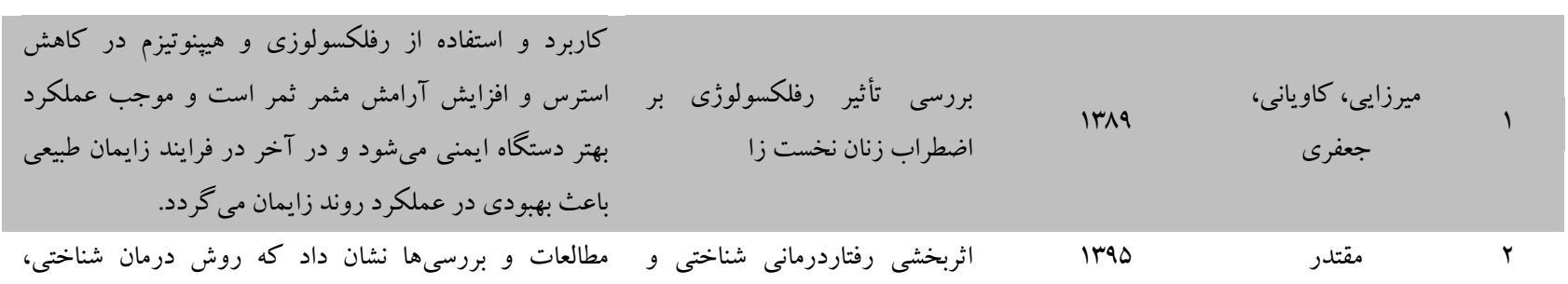


هيينوترابى بر اضطراب و افسردگى رفتارى و هيينوتيزم بر كاهش اضطراب و افسردگى سندرم

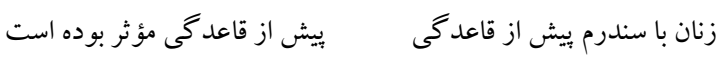

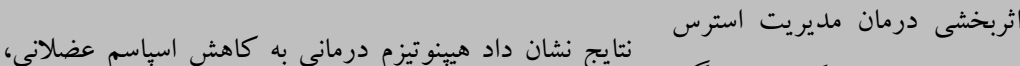

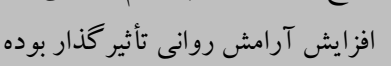

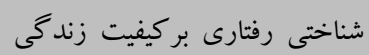
زنان مبتلا به صرع لوب كيجاهاهي

1 1\%я جو اهرى، نشاط دوست، مولوى، زارع

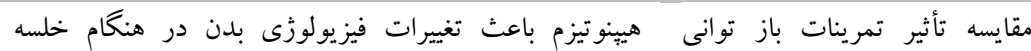

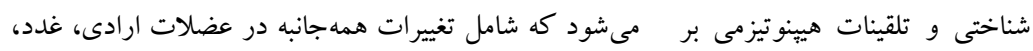

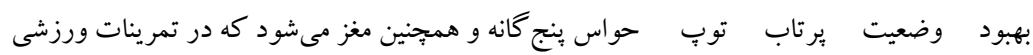

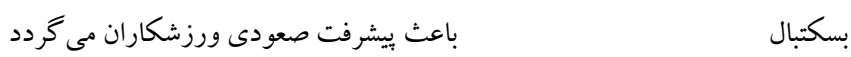

درمان شناختى رفتارى و هيينو تيزم درمانى باعث افزايش خود كار آمدى درد و كاهش شدت درد شده

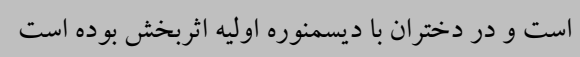

1 Ira9

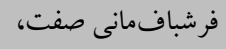
ه حاجلو

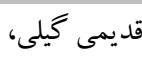
1490

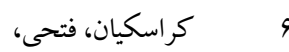

احدى ثربخشى هيينوتيزم بر كاهش درد

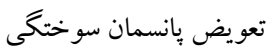

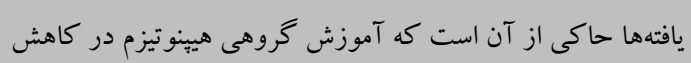

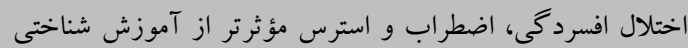
رفتارى كروهى بوده است اضتراب

بررسى كار آيى آموزش گروهى

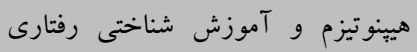
گروهى در كاهش افسردگىى، اضطراب

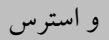
هيينوتيزم بهطور معنادارى موجب كاهش ادراكك حس درد،

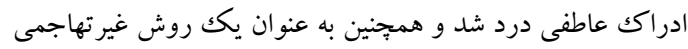

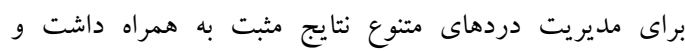
كنترل درد با هيينوتيزم براى بيماران

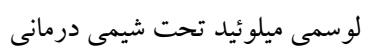
1490 فتحى، يور اصغر، جانبابايى

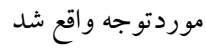

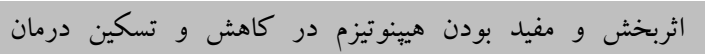

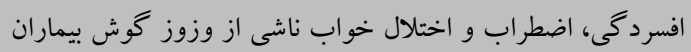
بسيار رضايتبخش بوده است

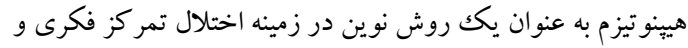

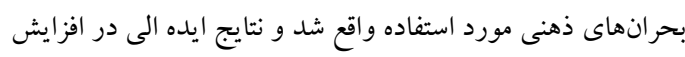
دقت و تمركز افراد بجاى كذاشت دورد

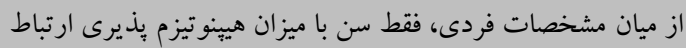

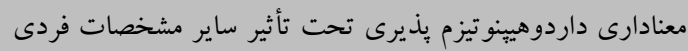

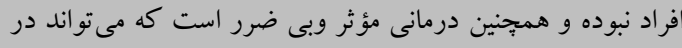

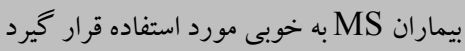
هيينوتيزم يكك روش درمان غير دارويى كارآمد در مديريت موردانيفاده فرار ديرد

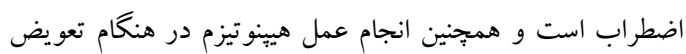

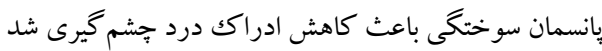

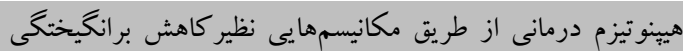

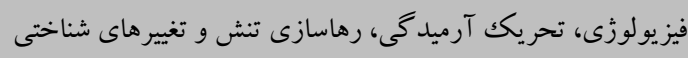

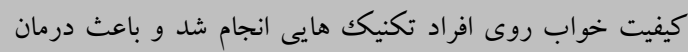

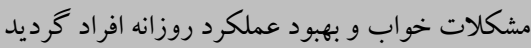

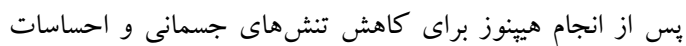

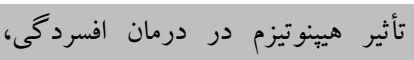

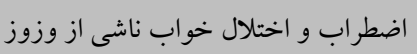
كوش اضطر

بررسى اثربخشى هيينو تيزم بر دقت و تمر كز

بررسى ارتباط بين مشخصات فردى و سطح سلامت روان با ميزان هيينوتيزم يذيرى زنان مبتلابه بيمارى مولتيل

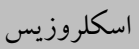
بررسى اثربخشى هيينوتيزم بر كاهش

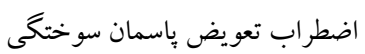

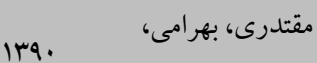

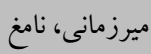

iraf $\quad 1$.

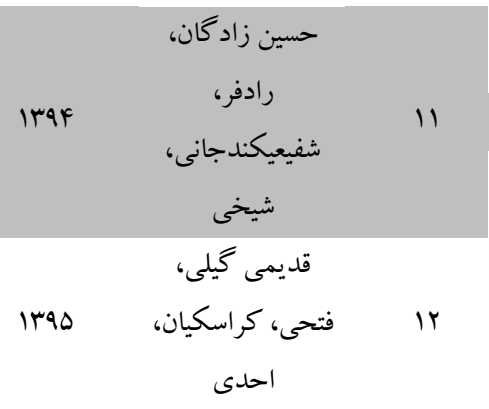

\begin{tabular}{|c|c|c|}
\hline 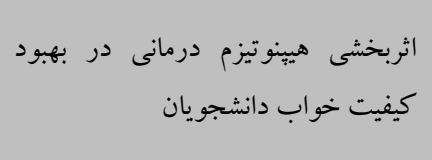 & Iraq & رحيمى بردنجانى، \\
\hline
\end{tabular}

اثربخشى هيينو ترابى در ميزان اضطراب

Irat 
منفى قوى باعث كاهش اختلالات شد و همجِين يك هفته پِ از

شريفى دراوردى،

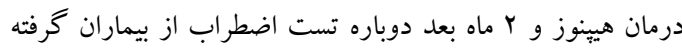

فتحى شد و نتايج رضايتبخش بود و اثر هيينوز باقى مانده بود

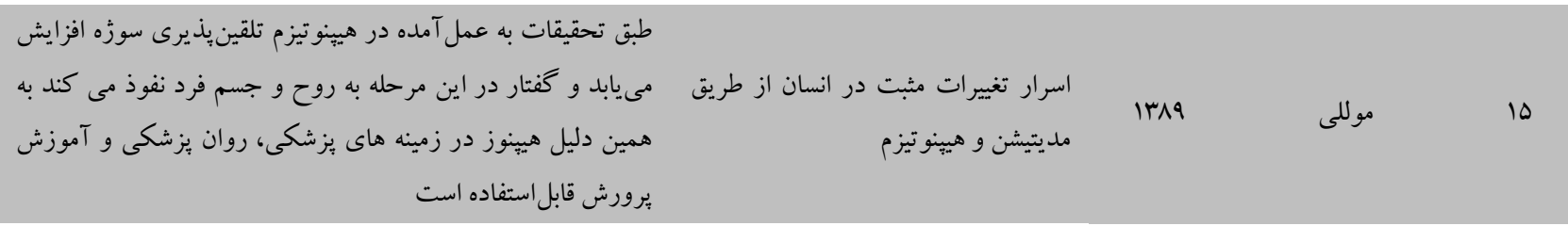

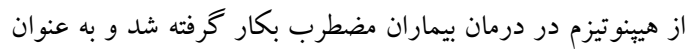

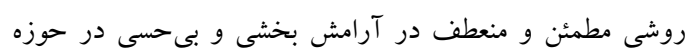
19 دندانيز شكى استفاده گر ديد ازجمله درمان هاى غيردارويى اين بيماران القاى هيينوتيزم و شل درد درد

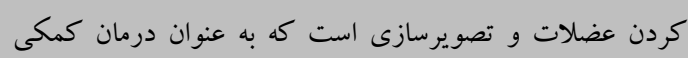

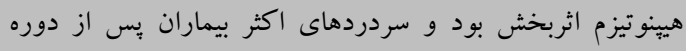
بررسى اثرهيينوتيزم در درمان سردردهاى تنشى اتر تروسين IrAY علوى، محجوبى درمان بهبود يافت هيزم تريحت طبق تحقيقات به عمل آمده هيينوتيزم تركيب (ادراكى

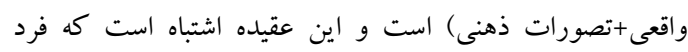
هيينوزبه طور كامل فاقد اراده است و همجينين هيينوتيزم اكثراً ماهيت هيينوتيزم و نظريه مؤلفين در مورد آن ماهيت هين

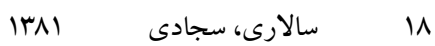
بهنوان درمان كملكى استفاده مىشود. با استفاده از تلقينها،تصويرسازىهاى ذهنى در زمئى زمينهى بهوبود

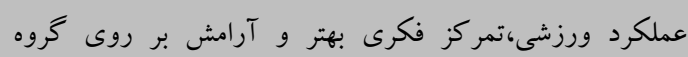

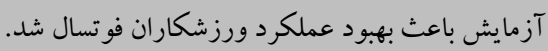

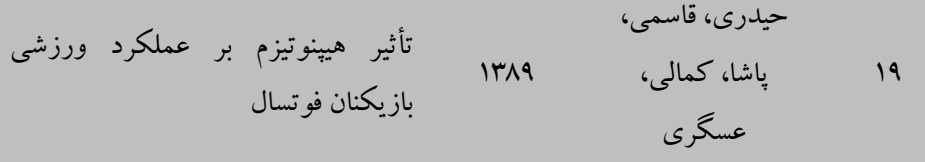

يردازش سيخنال EEG بهمنظور بررسى

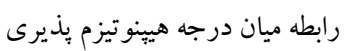
Ir/9

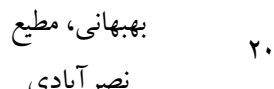

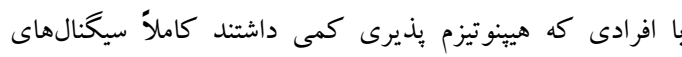
مغزى متفاوتى را دستخاه نشان داد

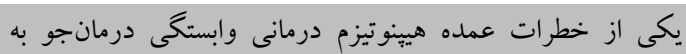

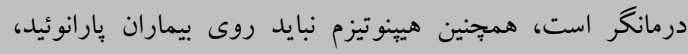

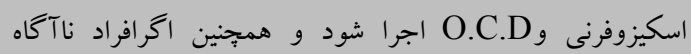

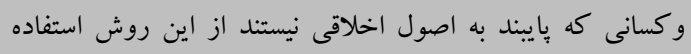

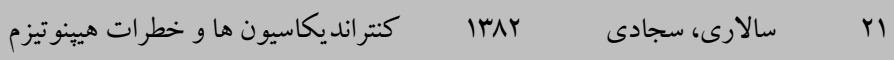

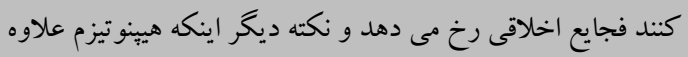

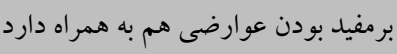

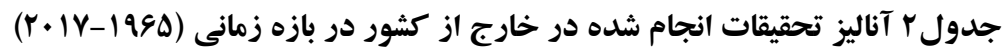

\begin{tabular}{|c|c|c|c|c|}
\hline نتايج يثزوهش & عنو ان يُزوهش & 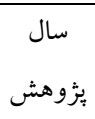 & 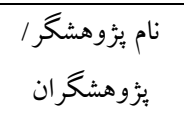 & رديف \\
\hline 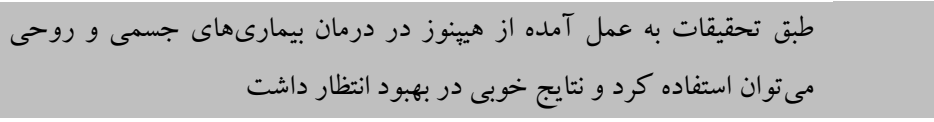 & ييشنهادهاى هيينو تيزم & 1990 & لو ينه، لودويخك & 1 \\
\hline 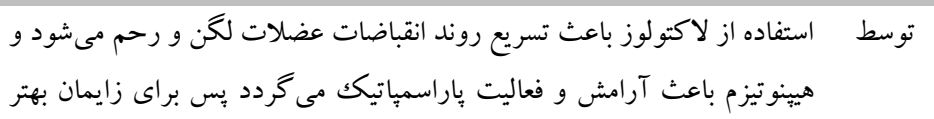 & هدولاسيون عذرا & $r . I V$ & بيو كرى، بورگر، & $r$ \\
\hline
\end{tabular}


براى جلو گيرى از فعاليت بيشازحد باراسمياتيك از لاكتولوز هم استفاده مى

شود

طبق تحقيقات به ثبت رسيده هيينو تيزم هم در مداخلات يزشكى و هم روان شناختى اثربخشى مناسبى دارد

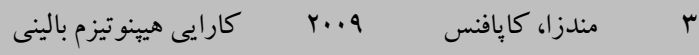

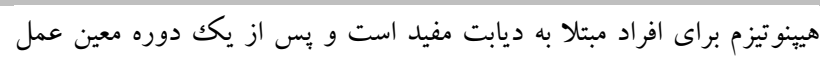

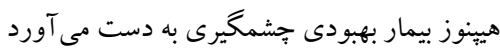

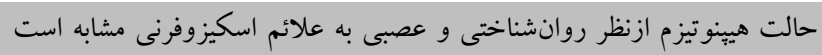
اما شواهد علمى و حقيقى براى حمايت از ارتباط اين دو وجود ندارد

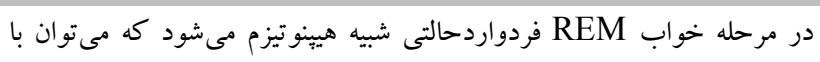
دادن تلقين محتويات ذهنى شخص را تغيير داد

هيينوتيزم به عنوان يكك روش غيرتهاجمى در درمان اسكيزوفرنى مزمن

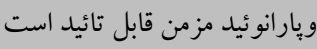

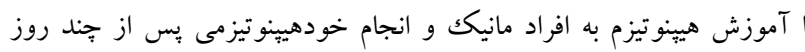

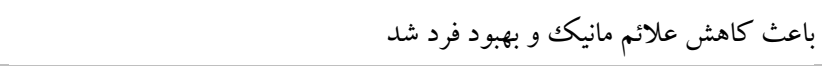
هيينو تيزم به عنوان يكك درمان

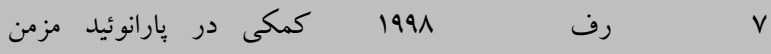

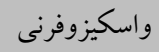

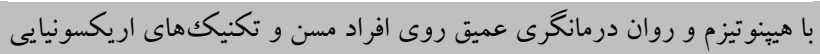

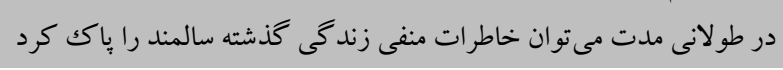
اثربخشى و كاربرد هيينوتيزم

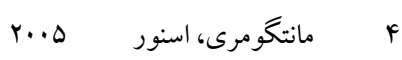

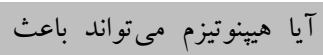

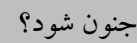
r... $\quad$ ف

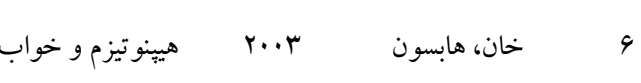

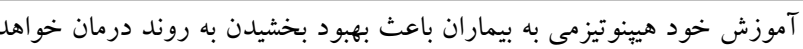
شد

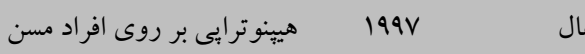
1999 م 19 اسرينيواسان

مانيك و ويروى مى كند اسجرونى هيينو ترايى

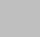

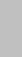
T

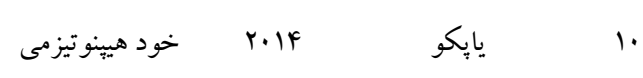
انجام تكنيك هاى ريلكسيشن باعث مىشود فرد به راحتى هيينوز شود r.lo بام

و عميق كردن خواب رم هم تأثير شايانى بر جاى

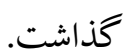
اما سؤال ديخر اين كه آيا هيينوترايى مىتواند بر روى

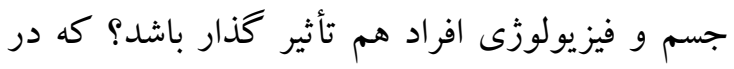

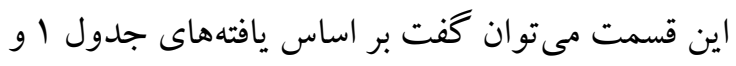

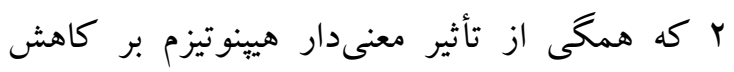
مشكلات جسمانى در بيزوهشهاى خود حمايت كردند، به جند مورد از آنها اشاره كرد كه شامل تأثير هيينو تيزم بر كاهش اسياسم عضلانى، تغييرات عضلات

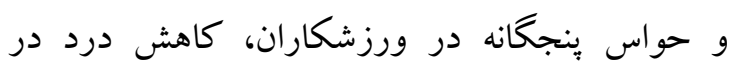
هنگام تعويض وِانسمان سوختكى، سردردهاى تنشى، كاهش ديابت و همجنين در دندانيزشكى تأثير بسزايى ليقي داشته است؛ و در مجموع از مطالعه به عمل آمده نتايج جالبتوجهى ديده شده است كه عبارتاند از:

\section{بحث و نتيجه كيرى} هدف از مقاله مرورى حاضر، ياسخ به به اين سؤالات

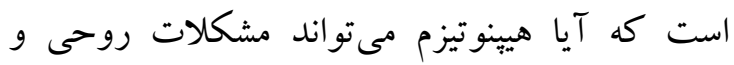
روانى افراد را برطرف كند يا كاهش دهد؟ يافتهها نشان

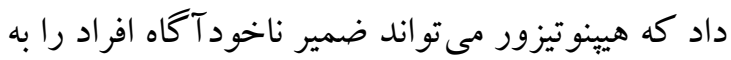
راحتى تغيير دهد و افكار، احساسات و اعمال انسانها را اصلاح نمايد؛ كه با توجه به تحقيقات انجام شده در زمينههاى: كاهش استرس و اضطراب توسط هيينوتيزم در زايمان طبيعى باعث حداقل درد ممكن در مادران شد همجِين در دختران با ديسمنوره اوليه حداقل احساس درد را تجربه كردند و هيبنو تيزم در بزوهش هاى اكثر محققين اضطراب، استرس و افسردگى رابه حداقل ممكن رساند و همجينين در اختلال وزوز گُش ابش 
معتادانى كه در مراحل اوليه و پايانى تركك هستند براى كاهش احساس درد و باكك كردن تجربيات ناخوشايند دوران استعمال دخانيات، تحقيقى صورت نخر فته است. طبق بيزوهشهاى انجام شده توسط محققان داخل كشور و خارج از كشور يافته ها دلالت بر اين موضوع

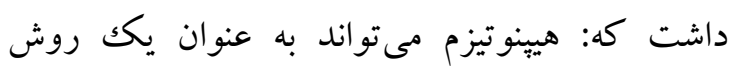

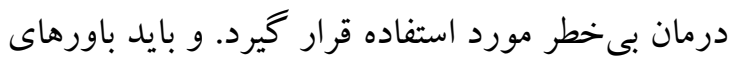
غلط درباره هيينوتيزم را در جامعه اصلاح كرد. بر اين اساس به يُزوهشخران يِيشنهاد مىشود كه در درمان

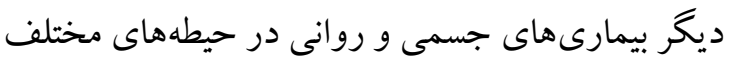
يزشكى و روانشناسى از اين شيوه درمانى استفاده نمايند و اين روش را در زمينهاى مختلف مورد بيزوهش و آزمون قرار دهند. اين امر خود منجر به روشن شدن رون بيشتر ميزان اثر بخشى اين روش درمانى خواهد شد. حال براى استفاده از هيينوتيزم بايد اين شيوه درمان لهرون مثمر ثمر رابه قشر خاصى از جامعه مانند روان شناسان،

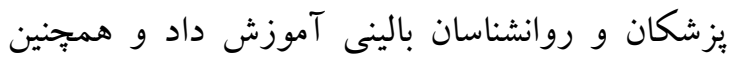
كلينيكهاى آموزش و درمان هيبنوتيزم را در جامعه كسترش داد تا مردم بهتر و علمىتر با اين شيوه درمان

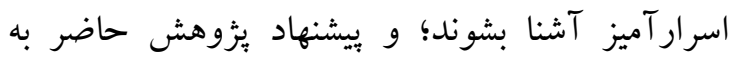

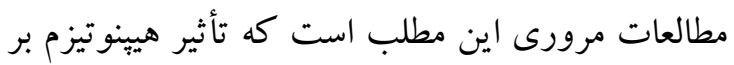
تكك تكك اختلالات به صورت جدا كانه بررسى شود.

\section{سياسگزارى}

در پيايان از خانم سييده نيكونزاد دانشجوى دكترى رشته برنامهريزى توسعه آموزش عالى دانش دانساه كردستان تشكر مى كنم كه در تهيه و تنظيم اين يثزوهش من را يارى كردند.

\section{References}

Alavi, M, Mahjubi Fard, M, Lashkaripoor, K and Fathi, M. (1382). The effect of hypnosis on the treatment of tension headaches.
الف) هيينو تيزم به عنوان كمكك درمانى در كنار درمان هاى كلاسيك كه براى مشكلات روانى و ذهنى استفاده مىشود، كاربرد دارد. ب) با توجه به علل زمينهاى ايجاد كننده مشكلات و و بيمارىهاى جسمى، هيينوتيزم با قرار دادن بيمار در حالت مادون آكاهى مىتواند بيمار را در وضعيتى قرار دهد كه يذيراى تلقينات درمانگر باشد و با تأثير گذارى مادي

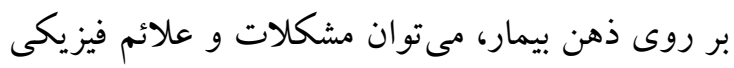
را هم بهبود بخشيد و در بهترين حالت برطرف كرد.

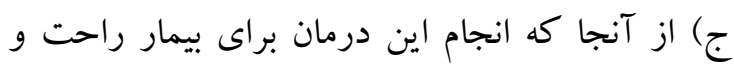
آرامشبخش است و بدون عوارض جانبى داروها است، كاربرى آن در درمانهاى روانى و جسمانى نسبت به مصرف داروها مقرون به صرفه بوده و سبب كاهش نياز بيمار به دارو مى گردد.

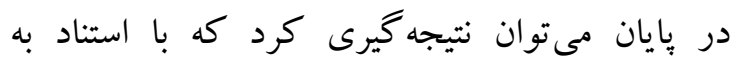
محدوديت هاى مقاله مرورى حاضر و جمعبندى حاصله از مطالعات صورت گرفته در زمينه هيبنوترابى، مى توان از اين تكنيك درمانى به عنوان ابزارى منعطف و مفيد در حوزه درمانهاى اختلالات روانى و جسمانى استفاده كرد. از محدوديتهاى اعمال شده بر روى كاربرد اين شيوه درمان بر روى بيماران مضطرب كه روز به روز بر تعدادشان افزوده مىشود بايد توجهات

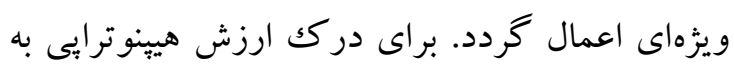

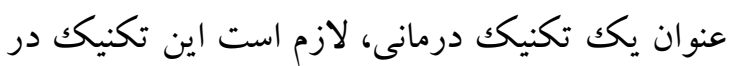
مقام مقايسه با ديخر تكنيك هاى آرام بخشى قرار گيرد، نياز به مطالعات كنترل شده بيشترى در اين حوزه از علم

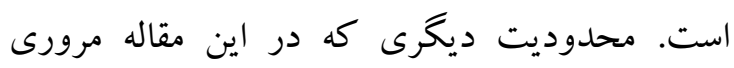
وجود دارد اين مطلب است كه يثزوهشهاى انجام شده بر روى افراد بيمار است و هيبنوتيزم بر روى افراد سالم

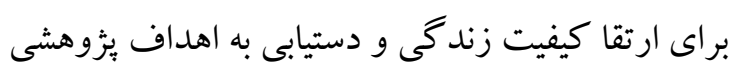
صورت نخرفته است و نتايج انجام شده هم قابل تعميم

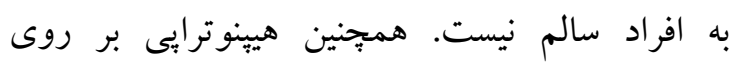


Magazine Association of Anesthetics and Intensive Care, 13,42, 22-25.

Baum LD. (2015). Hypnotic Relaxation Therapy: principles and Applications by Gary Elkins. Amj clinical Hypnosis, 57(1), 80-81.

Behbahani, S and Motih Nasrabadi, A. (1389). EEG Signal Processing to examine the relationship between hypnosis grade. Journal of Bioengineering, 4(1),36-47.

Capt. Clyde. Jones. (1975). The use of hypnosis in Anesthesiology. Chaim department Anesthesiology, Naval regional Medical centerSan Diego.2 (67), 122-125.

Farshbafte Manisefat, F, Abolqasemi, A, Barahmand, A Hajlu, N. (1396). Comparison of the Effectiveness of Cognitive-Behavioral Therapy and Hypnotherapy Therapy on the Effect of Pain and Pain Intensity in Girls with Primary Dysmenormea. Original research article Armagh Danesh, Joumal of Yasuj University of Medical Sciences, 22 (1), 78-103.

Fathi, F, Pour Ashgar, M and John Babaie, Q. (1395). Hypnosis pain control for myeloid leukemia patients under chemotherapy. Joumal of Faculty of Medicine, Mashhad University of Medical Sciences, 95(2), 71-81.

Ghadimi Gilli, A, Fathi, M, Kraskin, A and Ahadi, h. (1395). Effectiveness of Hypnosis on Reducing Anxiety. Journal of Faculty of Medicine, Mashhad University of Medical Sciences, 95(3), 363-371.

Ghadimi Gilli, A., Kraskin, A., Fathi, M. and Ahadi, H. (1395). The Effectiveness of Hypnosis on the Reduction of Pain Replacement Burning Dressing. The Scientific Journal of Mashhad Medical School, 18, 163-170.

Glyan Tehrani, Sh, Vaseg Rahimpour, F, Mehran, and Nikkhah, AS. (1385). The effect of meditating meditation on pain intensity and active phase of labor in nulliparous women. Journal of Faculty of Nursing and Midwifery, Tehran University of Medical Sciences, 21 (3), 51-61.

Hall, Steven. (1997). Hypnotherapy with older adults. view issue TOP. view issues toc. 14(1), 6879.

Heidari, A, Qasemi, D, Pasha, Gh, Kamali, A, and Asgari, p. (1389). The Effect of Hypnosis on the Performance of Athletes in Futsal
Players. The Thought and Thought Series (Applied Psychology), 4(160), 37-48.

Hossein Zadegan, F, Radfar, M, Shafiee Kandani, A, and Sheikh, Nasser. (1394). The Relationship between Individual Profile and Mental Health Level with Hypnotherapy in Women with Multiple Sclerosis. Quarterly Journal of the Iranian Scientific Society of Nursing, 3(11), 2345-2501.

Jawahiri, R, Neshat Dost, H, T, Molavi, H and Zare, M. (1389). The Effectiveness of Cognitive Behavioral Stress Management on the Quality of Life in Women with Temporal Lobe Epilepsy. Arak Medical Sciences Research Paper, 2( 51), 32-43.

Kahn, M.D. David, Hobson, M.D Allan.(2003). Dream and hypnosis as Altered stateds of the brain-maind. From the laboratory of neurophysiology, department of psychiatry, Harvard Medical school Massachusetts Mental Health center, Boston, MS, USA. 2003, 5(2), 58-71.

L 'Beaugerie 'AJ Burger, JF Cadranel. (2017). Modulation of orocaecal transit time by hypnosis. Papeles del psicology. 2(1), 117130.

LEVINE，JEROME， LUDWIG，ARNOLD M.(1965). Sugestion hypnosis. Psychopharmacology, 7, 123-137.

Lotfifar, B, Karami, A, Sharifi Drawari, P and Fathi, M. (1393). The Effectiveness of Hypnotherapy in Anxiety Reduction. Journal of Shahid Beheshti Medical Faculty, 37(3), 167-170.

Lynn SJ, Laurence JR, Kirsch I. (2015). Hypnosis, suggestion and suggestibility: An integrative model. Am joumal clinical Hypnosis, 57(3), 314-329.

M Hardman, M, J Drew, K and Agne, A. (1396). Psychology and Exceptional Children Education. IN: Hamid Alizadeh, Kamran Kenji, Majid Yousefi Loyeh and Fariba Yemagari, Editors, 15 nd ed. Tehran:Raven press,456-614.

M. Elena ‘Mendoza Antonio capafons. (2009).Eficacia de la hypnosis clinica. Resumen de evidencia empirica.Papeles del psicology, 30(2), 98-116.

Mehrani, J, and Pour asghar, M. (1394). The application of hypnosis in dentistry. Joumal 
of Mazandaran University of Medical Sciences, 25(33), 352-360.

Mirzai, F, Kaviani, M, and Jafari, p. (1389). The effect of reflexology on the nulliparous women's anxiety. Journal of Faculty of Nursing and Midwifery, Tehran University of Medical Sciences, 16(1), 65-71.

Moghtaddari, Sh, Bahrami, E, Mirzamani, M and Namegh, M. (1390). Effects of pancreas in the treatment of depression, anxiety and tiredness. Zahedi Joumal of Research in Medical Sciences, 13 (3), 20-24.

Moghtadr, Layla. (1395). The Effectiveness of Cognitive Behavior Therapy and Hypnotherapy on Anxiety and Depression in Pregnant Women. Journal of Nursing and Midwifery, Joumals Joumal, 93, (81), 95105.

Mohammadzadeh Ebrahimi, A, Rahimi Predendjani, T. and Taghvai Nia, A. (1396). The Effectiveness of Hypnotherapy in Improving the Sleep Quality of Students. Shahid Beheshti University Medical School, 41(4), 10-16.

Molely, M. (1389). Secrets of positive changes in humans through mediation and hippopotamy. 2nd ed. Tehran: Raven press, 23-25.

Montgomery, Guy H ،Schnur, Julie B.(2005). Eficaciay aplicacion de la hypnosis clinica. consejo general de colegios oficiales de psicologos madrid, espsna. Papeles del psicology, 25( 89), 3-8.

Rahnamay Rodposht, F and Rostami Mazoyi, N. (1394). A Review of Psychological Theories in Management Accounting Research. Quarterly Journal of Management Accounting, 8 (26),74-89.

REF, CROSS.(1998). Hypnosis as an adjuvant treatment in chronic paranoid and schizophrenia. Indian Joumal of Psychiatry, $15(4), 223-226$.

Salariyah, E and Sajjadi, S. (1381). The nature of hypnosis and the author's theory about it. The horizon of the horizon, 8, 16-25.

Salariyah, E and Sajjadi, S. (1382). Contraindications and hypnosis. Joumal of Horticulture, 4,(1), 36-44.
SURESH TR ،SRINIVASAN T. N. (1999). Mania Following Hypnotherapy. Indian Journal of Psychiatry, 36(1), 34-35.

Watkinson J. (1992). Hypnonalytic techniques: the practice of clinical hypnosis. published by Irvington publication. new York, USA, 2, 265-290.

Weizenhoffer AM. (2014). The practice of Hypnotism. $2^{\text {nd }}$ ed. New York: Wiley, 156163.

Zarei, A and Aghayi, H (1390). Comparison of the effect of cognitive rehabilitation exercises and hypnosis on improving the status of ballistic basketball throwing. Quarterly joumal of psychology, 1(3), 80-96.

Zarei, A and Aghayi, H (1394). Comparison of the effect of cognitive rehabilitation and hypnotization on improving the status of basketball ballpost. Quarterly Joumal of Shaherood Psychology, First Year, 3, 80-88. 